\title{
PSYCHOLOGICAL CONTENT IN ISLAMIC EDUCATION TEXTBOOK: A REQUIREMENT IN CHARACTER BUILDING GOALS ACHIEVEMENT
}

\author{
Lenny Herlina \\ Universitas Mataram, NTB, Indonesia \\ herlinalenny@gmail.com
}

\begin{abstract}
The study aims to find out whether psychological content is presented in Islamic education textbooks or not. The method used was library research. The data collection technique used was by reviewing the document and descriptive analysis. The textbooks studied were: first, Islamic Religious Education and Character student textbook of Class 10 by Kemendikbud RI in 2017, second, the book entitled "Spirituality, Values and Mental Health: Jewels for the Journey" edited by Mary Ellen Coyte, Peter Gilbert, and Vicky Nicholls. The research result shows that there is not psychological content within the books. While according to the researcher, psychological content is very important to enrich Islamic Education learning material as a means to instil religious awareness related to spiritual values, such as good personality both personally and socially as the initial and final objective in the Islamic Religious Education learning process. The research result is expected to influence Muslims with individual and social piety by eliminating the self-righteousness attitude that often creates inter-faith and internal Muslim bullying as well as eradicating the assumption that Muslims are intolerant and not humanist as part of the indications of the achieved character building.
\end{abstract}

Keywords: Islamic education, Psychology learning material, character building.

\section{INTRODUCTION}

Education is mankind's primary needs as the greatest investment in building and forming the truly human (Baharun, 2016: 96-107), it is an inevitability that God trusted human since the beginning, and focuses on 'civilizing people' (Sidek, 2006: 14). In the Qur'an and Hadith, there are found several words showing education meaning, i.e.: Rabba which means nurture as in Chapter Al-Israa: 24, 'allama which means taught as in the Chapter AlAlaq: 5, and addaba which mean educate, as in the Hadith narrated by Imam Addailamy (Achmadi, 2004: 24). 
Herlina, L. (2020). PSYCHOLOGICAL CONTENT IN ISLAMIC EDUCATION TEXTBOOK: A REQUIREMENT IN CHARACTER BUILDING GOALS ACHIEVEMENT. Jurnal Tatsqif, 18 (2), 207-222. https://doi.org/10.20414/jtq.v17i2.2800

The common term used by the experts to point the meaning of Islamic education, i.e. ta'lim, tarbiyah, and ta'dib, while Muhammad Naquib Al-Attas in his book entitled Konsep Pendidikan Islam only uses the term ta'dib because it covers the insight of knowledge and deed as the essence in Islamic Education (Watik, 1995: 142). Buya Hamka as one of the religious figures and renowned scholar in the country put education as a process (ta'lim) refer to maintain and develop the student's whole potential (fitrah), both physical and spiritual and deliver a mission (tarbiyah), both vertical and horizontal (Hamka, 2015: 283).

Philosophically, Islamic education aims to form al-insanul kamil, or the truly human who represents the Qur'an values by achieving religious, cultural, and scientific dimension (Zuhairini et al., 2004: 155). In achieving it, Islamic education must be directed to horizontal dialectic dimension toward each other and vertical submission dimension to Allah (Daradjat, 2014: 56). According to Ki Hajar Dewantoro, education aims to teach numerous knowledge to a student hoping that they will become the true and perfect human, their life is under the society and nature, as well as a nation and community's effort in preparing the young generation for the continuity of a better life (C. Muali. 2017: 105-117), improving the better intellectual and individual spiritual balance among the students, not just as a citizen, but also become the truly human for himself. Ideally, education brings great contribution to give the solution in humanitarian crisis which currently struck the life. Starting from the education, we want to generate honest people, passionate, hard worker, not lazy, brave, creative, fond to cleanliness, tolerant, and so forth (Al Attas, 1980). Hence, in a wider meaning, it can be said that Islamic education emphasizes the submissive and mankind caliphate objective, i.e. preserving human relationships with other God's creation as a manifestation of the caliphate responsibility on the earth, as well as feedback relation between human and the surrounding nature harmoniously (Nizar, 2008). 
Herlina, L. (2020). PSYCHOLOGICAL CONTENT IN ISLAMIC EDUCATION TEXTBOOK: A REQUIREMENT IN CHARACTER BUILDING GOALS ACHIEVEMENT. Jurnal Tatsqif, 18 (2), 207-222. https://doi.org/10.20414/jtq.v17i2.2800

In Indonesia, since 2011, the Government through National Education Department uses a character-building model containing 18 values in developing nation's character and cultural education, whereby the entire level of education must insert the character building in its learning process, including Islamic schools which already have obligatory content in moral theology. As for the 18 values in character building mentioned above are: 1) Religious, it is an obedient attitude and behavior in performing their religious teachings, being tolerant toward other religious worshipping, and living in harmony with other religious believers. 2) Honest is a behavior that tries to make someone a trustworthy person in the action, word, and work. 3) Tolerance is the attitude and action which respects diversity in religion, tribe, ethnic group, opinion, other people's attitude and action that are different from oneself. 4) Discipline in action shows an obedient and orderly manner toward various rules and regulations 5) Hard work in the action shows an obedient and orderly manner toward various rules and regulations. 6) Creative thinking and performing something to create a new way or outcome different from the one someone has. 7) Independent attitude and attitude which is not easily dependent on other people in solving the assignments. 8) Democratic is the way of thinking, attitude, and act judging that everyone has the same rights and responsibilities. 9) Curiosity and action that always try to find out deeper and wider from something we learn, see, or hear. 10) Nationality spirit is the way of thinking, acting, and having insightful that places the state and nation's interest above oneself and one's group. 11) Love in the homeland is the way of thinking, acting, and having insightful that places the state and nation's interest above oneself and one's group. 12) Appreciating achievement, attitude, and action which encourage someone to create something useful for the society, acknowledge and respect others' success. 13) Friendly/Communicative is an attitude and action that encourage someone to create something useful for the society, acknowledge and respect others' success. 14) Loving peace is an attitude and action that encourage oneself to create something useful for the society, acknowledge and respect others' success. 15) 
Herlina, L. (2020). PSYCHOLOGICAL CONTENT IN ISLAMIC EDUCATION TEXTBOOK: A REQUIREMENT IN CHARACTER BUILDING GOALS ACHIEVEMENT. Jurnal Tatsqif, 18 (2), 207-222. https://doi.org/10.20414/jtq.v17i2.2800

Fondness to read is the habit to spare time in reading various reading texts that gives the one wisdom for oneself. 16) Concern in environment is attitude, and action that always try to prevent damage toward the environment and its surroundings, and development efforts to fix the environmental destruction which has occurred. 17) Social concern is an attitude and action that always want to help the society and other people in need. 18) Responsibility is an attitude and behaviour in an individual who performs task and obligation which someone should do to themselves, the society, and the environment (nature, social, and culture), the state and God the Almighty, (Pusat Kurikulum Departemen Pendidikan Nasional 2010).

Based on the definition and Islamic objectives as well as the mandate of character building by Sisdiknas above, the writer of this study starts from one research question: how far the extent of Islamic Religious Education textbook has included learning material containing psychology to achieve the character building?. To answer the question, the researcher studies student textbooks on 'Islamic Religious Education and Character' of class 10 by Kemendikbud RI in 2017 as the main book and psychology book entitled "Spirituality, Values and Mental Health: Jewels for the Journey" edited by Mary Ellen Coyte, Peter Gilbert and Vicky Nicholls as a supporting book.

\section{METHOD}

The method used was library research. The data collection technique used was by reviewing the document and descriptive analysis. The textbooks studied were: first, Islamic Religious Education and Character student textbook of Class 10 by Kemendikbud RI in 2017, second, the book entitled "Spirituality, Values and Mental Health: Jewels for the Journey" edited by Mary Ellen Coyte, Peter Gilbert, and Vicky Nicholls. 
Herlina, L. (2020). PSYCHOLOGICAL CONTENT IN ISLAMIC EDUCATION TEXTBOOK: A REQUIREMENT IN CHARACTER BUILDING GOALS ACHIEVEMENT. Jurnal Tatsqif, 18 (2), 207-222. https://doi.org/10.20414/jtq.v17i2.2800

\section{RESULT AND DISCUSSION}

\section{Psychological content in Islamic Religious Education Textbook}

Up until today, the educational experts say on the importance for a teacher to master the knowledge in children's development from toddlers to adults, the psychology of the students or educational psychology (Mahmud, 2010). It is because the teacher's task is as loco parentis, a guiding role to (1) present numerous information in the learning-teaching process, (2) assist every student in overcoming personal issues, (3) evaluate every activity undertaken, (4) allow the student to learn according to their characteristics, and (5) know and understand every student either individual or in the group (Ahmadi \& Supriyono, 2003: 116-117), as well as instruction in Constitution Number 14 of 2005 on Teacher and Lecturer in the Article 20 (2008: 20).

Starting from the researcher's experience who has been a teacher for over 12 years in Senior High School, it can be concluded that in education, mastering basic psychological knowledge is an inevitability. Because, generally during the learning process, students with family background or community and with all their owned potential such as below-average intelligence, or student's delinquency usually are considered as the cause of the difficulties in learning process and achieving its objectives. Whereby the teacher does not only stop teaching, telling, advising, and punishing if the students make mistake. However, they must thoroughly start and know-well the student, starting their family and community background, intellectual ability, hobbies, and character. This is only for the student can determine the teaching method or select the right approach for each student according to its heterogeneity. As the factors that can influence the type of individual differences according to Oemar Hamalik (2011:181), those are Intelligence, Aptitude, Physical Fitness, Social and Emotional Adjustment, and Home Background.

Then, how about the learning material as an important part of the learning process? How far the extent of learning material, in this case, Islamic 
Herlina, L. (2020). PSYCHOLOGICAL CONTENT IN ISLAMIC EDUCATION TEXTBOOK: A REQUIREMENT IN CHARACTER BUILDING GOALS ACHIEVEMENT. Jurnal Tatsqif, 18 (2), 207-222. https://doi.org/10.20414/jtq.v17i2.2800

Religious Education textbook, contains the message that is wanted to be instilled? And why does psychological content as the catalyst in the achievement of spiritual education for the student become important?

Generally, Psychology is the science of human and animal behavior, and its application on human issues (Harsanti, 2013: 2). Commonly, psychology is the science studying spiritual/mental. Psychology does not study spiritual/or mental directly because of its abstract nature, however, it is limited on the spiritual/mental manifestation and expression in the form of behavior and process, or its activity. Therefore, it can be defined that psychology is the science of studying behavior and mental process. Because the study aims to find out how far the extent of the textbook inserting psychological content within the existing learning material. Psychology mentioned by the writer is not psychology as a subject, but psychology in the form of materials related to spiritual/mental manifestation and expression of an individual or group which is possibly contained on a discourse, analogy, wisdom stories, case study or morals guidance contained in the Islamic Religious Education.

The learning material is wrapped as a material presented in the learning process, contains facts, principles, and norms, related to rules, values, and attitudes, as well as a set of motoric skill/action contains the message, information, and illustration in the form of fact, concept, and process related to the certain topic which is directed to achieve learning purpose (Depdiknas, 2008:199). It is as the learning sources utilized indirectly while the learning material is the supporting material functioned as supplementary. The instance is that textbook, magazine, video program, and learning comic. This learning material is commonly arranged outside the curriculum, but it has a close relationship with the main objective, which deepens and enriches the students (Sukriniam. 2017:12-14.)

In this writing, the researcher chooses to review a textbook, which is Islamic Religious Education and Character in class 10 by Kemendikbud RI 2017, by focusing: Chapter 6: Living with Glory, and Chapter 9: Exemplifying 
Herlina, L. (2020). PSYCHOLOGICAL CONTENT IN ISLAMIC EDUCATION TEXTBOOK: A REQUIREMENT IN CHARACTER BUILDING GOALS ACHIEVEMENT. Jurnal Tatsqif, 18 (2), 207-222. https://doi.org/10.20414/jtq.v17i2.2800

the Prophet Muhammad PBUH (Peace Be Upon Him) in Madinah Period. This Islamic Religious Education and student's character textbook in class 10 is prepared by the government in the implementation of the 2013 curriculum (K13) and has been reviewed by many parties under the Ministry of Education and Culture of Republic Indonesia and used in the K13 initial stage implementation, and a dynamic document that always can be revised and updated or upgraded according to the condition and changes of the era.

Chapter 6 starts with the story of Prophet Yusuf with three main messages, those are: first, exemplifying the prophet Yusuf who succeed in controlling himself from the temptation of a beautiful woman, a wife of an Egypt's officials, second, prophet Yusuf is always kind to those who makes him in prison by not taking revenge to them, so does to his brothers who have casted and separated him from his father, third, upholding brotherhood, instead of holding a grudge, Prophet Yusuf as an official chose to help and reunite his family again in the wonderful brotherhood. Here, we can get the lesson taught to the student is fixated on spirituality building that would be perfect and complete if the learning material is inserted by discussion on psychology related to how human's psychological condition in general, either its nature or characteristics when dealing with the situation as had been faced by Prophet Yusuf and then it is explained how human will be able to build its well mental-spiritual, so that, it can exemplify Prophet Yusuf's character.

Later on, in chapter 6, it is explained the definition of self-control, positive thinking, and brotherhood. Self-control (mujahadah an-nafs) is meant as an effort in controlling oneself from many things that can harm oneself or others such as greedy and covetous. In Islam, self-control is also known as as-saum or fasting as one of the mediums in self-control. The explanation about other people in this chapter, as the writer noted, is also inadequate. It would be good if the addressing to other people here are described by everyone expects himself, either family or not, either male or 
Herlina, L. (2020). PSYCHOLOGICAL CONTENT IN ISLAMIC EDUCATION TEXTBOOK: A REQUIREMENT IN CHARACTER BUILDING GOALS ACHIEVEMENT. Jurnal Tatsqif, 18 (2), 207-222. https://doi.org/10.20414/jtq.v17i2.2800

female, old or young, the same religion or not. Either the same ethnic or not, the same nation or not, the same language or different, close or far. Why does it must be mentioned? Because according to the writer's concern, it will affect the student's understanding that in the era of distance and space, there is no longer a boundary with the existence of the virtual world as in today, an individual or a group can give benefit or harm to other people through the limitless spaces of information because it can be accessed by everyone, whenever. So does the example of self-control from greedy and covetous, the writer notes that it is far from enough. Humans have many traits as a nature, such as they want to be acknowledged, to have, to dominate, and other human traits.

In the book of "Spirituality, Values and Mental Health: Jewels for the Journey" it explains: it is not merely caused by politic, a person who becomes a minority believer of an area, especially the religion that is regarded to be negative has big opportunity to be discriminated, as expressed in the collection of people's life journey who are psychologically depressed, so that, it brought them to mental treatment. It is caused by the faith they have chosen turns into bullying victims and creates hatred toward the people who have different faith around them. Likewise, when someone feels economically wronged, it may be that instead of self-introspection, they cannot refrain from blaming all the causes of their failure as someone else's fault. In this case, the description of the psychological point of view becomes very important to be inserted to open the insight and to deepen the student's understanding of the importance of self-control that can cover many things.

Afterward, this chapter explains the meaning of positive thinking (husnuzzan), it is meant as the attitude to always think positively toward other people' do. The opposite of this attitude is prejudice (suúzzan) or negative thinking. In Islam, positive thinking is categorized into three, i.e. positive thinking to Allah, to ourselves, and other people. What is mention by other people, it should be explained in the learning material above. Why do 
Herlina, L. (2020). PSYCHOLOGICAL CONTENT IN ISLAMIC EDUCATION TEXTBOOK: A REQUIREMENT IN CHARACTER BUILDING GOALS ACHIEVEMENT. Jurnal Tatsqif, 18 (2), 207-222. https://doi.org/10.20414/jtq.v17i2.2800

that so? Because according to the researcher, it will affect on a better and thorough comprehension for the student in understanding how a Muslim can live in a noble life by applying positive thinking character and attitude by applying it on the attitude and behavior. It is not only related to positive thinking to Allah as the manifestation of the first and sixth pillars of faith and how to be positive to ourselves as a part of grateful manifestation and how to have positive thinking to other people as the manifestation to uphold humanity and justice that is contained within asmaúl husna, including the other faith believer. This will be emerging the importance of psychological dimension presented to the student, that positive thinking to Allah will bring great peace of mind, positive thinking to ourselves will bring the individual to a positive and better-fighting ethos, and positive thinking to other people will lead to the safety and peace community's life, far from violence, verbally or physically.

The third definition is on brotherhood (ukhuwah) which is not only those who are related and kinship, but also brotherhood based on the same faith and the same humanity. According to the writer's opinion, the definition mentioned in the book is correct and complete, however, on the further explanation, it is only fixated only blood ties relationship and kinship as well as the same faith. While brotherhood based on humanity is not explained yet. This is very unfortunate, considering the social problems such as Islamophobia that many Muslims face today come due to weak brotherhood ties on the basis of humanity (Young European Muslims, 2002).

If we noted thoroughly, in chapter 9 , it is only explained on the story in God's Messenger PBUH as generally found in the book such as Sirah Nabawiyah, without inserting psychological element whereas it is interesting in the current era. This is very unfortunate, considering the role model inherited by God's Messenger covers all elements in life, starting from social interaction in education, politic, economy, security, and how to socially interact between religious believes such as Jewish, Christian, Zoroaster. What 
Herlina, L. (2020). PSYCHOLOGICAL CONTENT IN ISLAMIC EDUCATION TEXTBOOK: A REQUIREMENT IN CHARACTER BUILDING GOALS ACHIEVEMENT. Jurnal Tatsqif, 18 (2), 207-222. https://doi.org/10.20414/jtq.v17i2.2800

comes from God's Messenger mostly emphasizes on humanity, it is very clear when the Messenger united Anshar people and Muhanirin (Internal Ummah) and how the Messenger set the agreement or MOU with other religious believers in Madinah, so that, it created harmonious life at that time.

The principles of humanity presented clearly when the Messenger preached during Wadak Pilgrimage (farewell pilgrims), firmly he reminded: it is forbidden to make bloodshed and gained wealth by indulging manner, of course, this is applied to Muslim internal ummah or inter-religious believers, Islam through the Messenger reminds the follower not to violently treat others, related to the spiritual (killing or fighting for religion has clear requirements, i.e. it can be done when our religion is insulted, forbidden to perform prayer to our faith, and expelled from our resident. If these requirements are fulfilled it might be permitted for Jihad, however, if the terms are not fulfilled, we are forbidden to be violent such as taking other lives and wealth. What if the sleaziness was carried out by an outsider through the virtual world? So, of course, the Muslim ummah has the right to defend and defend themselves in the same way, namely through the virtual world as well, psychologically this will bring serenity in life, it is because every individual or group surely will understand that we do not as other people do upon us, so we will not do as well to other people, for instance, insulting other's people religion, of course they will fight back to insult our religion as well. If we persecute others physically, it will also possible that other people will hurt us, and so on, so it will be hard to create peace.

The instruction to avoid usury and persecution (Ibn al-Arabi. 1957: 321), actually due to its harm, either individual or social, even though it is religious school differences (khilafiyah), but usury still has the opportunity to enrich one party, which is the lender, while the borrower is on the persecuted position, therefore Islam strongly forbids usury, as the origin of economic inequality. If it is explained psychologically, economic inequality will lead to despair, pessimist, far from gratitude, and may create many criminal actions, 
Herlina, L. (2020). PSYCHOLOGICAL CONTENT IN ISLAMIC EDUCATION TEXTBOOK: A REQUIREMENT IN CHARACTER BUILDING GOALS ACHIEVEMENT. Jurnal Tatsqif, 18 (2), 207-222. https://doi.org/10.20414/jtq.v17i2.2800

even crimes in the name of religion are actually on the ground of economic issues.

The command to treat the wife in gentle and prohibition to commit sins. Psychologically, the chaos in a household will give impact significantly on the youth generation adversity, this is due to the broken home factor either because of inharmonious father-mother relation, economy problem, or adultery sins which lead to mental destruction among the family members. Seeing the great impact, Islam strongly stresses for every family to help each other to keep away from the hellfire (either in the world or afterlife), because Islam is not expected the weak young generation, instructing to be forgiving. Holding onto a grudge will cause endless chaos. Muslim and Christian are always fixated on crusade-war history. Muslims and Jews always claim as the best generation. Sunni and Shi'á follower are never at peace, and others who always quarrel, until psychologically it is filled with hatred activities than creating a way to improve ourselves.

Upholding brotherhood and the equality of rights among mankind. Have we ever heard the story that in case of an accident on a highway, we would ask the victim about their religion first? The answer is no. Have we ever felt hurt by the unjust treatment of others? The answer is yes. In Islam, we are warned not to discriminate against other people because psychologically we have the same basic nature, which the desire is to be respected. When we discuss brotherhood based on humanity, whatever the faith and origin, we will always be fair. We can learn much from the stories written in the book entitled "Spirituality, Values and Mental Health: Jewels for the Journey", whereas every individual wants to be appreciated on the faith chosen, whether they are Hindu, Cristian, Jew, Islam, or other cultural religions believers.

Unfortunately, psychologically the explanation of the seventh message delivered by God's Messenger during wadak pilgrimage is not mentioned in chapter 9 of the textbook. Therefore according to the researcher, the story 
Herlina, L. (2020). PSYCHOLOGICAL CONTENT IN ISLAMIC EDUCATION TEXTBOOK: A REQUIREMENT IN CHARACTER BUILDING GOALS ACHIEVEMENT. Jurnal Tatsqif, 18 (2), 207-222. https://doi.org/10.20414/jtq.v17i2.2800

presented will be only a history lesson without resulting in any further indepth thought of the students.

\section{An Inspiration Morality, Values and Mental Health}

Imam Al-Ghazali divides humans into four parts, i.e. al-Ruh, al-Nafs, alQalb, and al-Aql. 1) Al-Ruh, is part of the human body, which is the substance that is so subtle sourced from the heart which becomes the center and the core of all blood vessels spread all over the human body. 2) Al-Nafs, has some meanings such as soul, spirit, life, mind, and so on. 3) Al-Qalb refers to the spiritual aspect, non-material subtle substance functions to know everything and able to reflect something like a mirror reflecting an image which reflects the essence depend on the Qalb nature, correspond to sense, desire, deeds, and love. As long as the heart is clean from the obstacles covering it, then it may catch the existing essence. Even in the Qalb, ma'rifat occurs. Qalb is filled by knowledge through reading, hearing, feeling, observing, examining, and then digs up deeper Qalb through uzlah, khalwat, mujahadah, muraqabah, musyahadah. 4) Al-Aql, etymologically has the meaning of 'contain' (AlImsak), union (Al-Ribath), maintain (Al-Hajr), forbid (Al-Nahy), and present (Al-Man'u), Al-Ghazali. Ihya Ulum al-Din (1992). Terminologically, a sensible person is the one who is able to contain and hold their desires. The mind is interpreted as energy that is able to obtain, store, and brought out knowledge. Meanwhile, psychologically, the mind has cognition function (creativity), which covers all shapes of cognitive experiences such as observing, seeing, arguing, imagining, thinking, predicting, considering, assuming, and judging (Mujib et al., 2003).

The researcher concludes that psychological content is very important to be inserted to enrich the learning material. An inspiring book that inspires the writer to believe that it is important to insert psychological content in the textbook, is entitled Spirituality, Values, and Mental Health: Jewels for the Journey" edited by Mary Ellen Coyte, Peter Gilbert, and Vicky Nicholls. A 
Herlina, L. (2020). PSYCHOLOGICAL CONTENT IN ISLAMIC EDUCATION TEXTBOOK: A REQUIREMENT IN CHARACTER BUILDING GOALS ACHIEVEMENT. Jurnal Tatsqif, 18 (2), 207-222. https://doi.org/10.20414/jtq.v17i2.2800

collection of important essays based on the writers' life stories initiated by John Swinton and the canter of spirituality, health, and disability, Aberdeen University on January 2007.

The story of Maryam (a pious Muslim), Premila Triverdi (a Hindu), and Andrew Wilson, Andrew Wilson as well as Veronica Dewan (who are Christian). They are treated mentally due to the pressure of religious belief (Peter Gilbert and Vicky Nicholls, 2007). Religious belief can cause hardship to a person either physically or mentally when facing the hater. However, in the end for those who try to survive, their faith will help to cure them, when the believer understands and believes in whatever comes from the religion as the source of happiness both present and future. For those who are succeeding, it is a good thing. However, every individual must realize that humanity has different strengths in dealing with problems. We should understand that being kind and fair towards other people's religious choices is the right way as stated in Islamic teachings, as in God's the Almighty Words in Chapter al- Kaafiroon verse 1 until 6, which means: "Say: "O disbelievers, (1) I do not worship what you worship. (2) Nor are you worshippers of what I worship. (3) Nor will I be a worshipper of what you worship, (4) Nor will you be a worshipper of what I worship. (5) For you is your religion, and for me is my religion". (6)" (QS. Al Kaafiroon: 1-6).

Refer to the above matter, the teacher or the textbook writer needs to understand mental health issues (psychology) as part of the spiritual dimension, so that, the student can be easier to understand the real-life especially related to social-religious and cultural issues by absorbing it with the good religious teaching with the wide range of endless meaning, and by instilling awareness that every religious believer has the right to be respected. Eventually, the awareness will very correspond to the diversity as the insight of the Indonesian nation. 
Herlina, L. (2020). PSYCHOLOGICAL CONTENT IN ISLAMIC EDUCATION TEXTBOOK: A REQUIREMENT IN CHARACTER BUILDING GOALS ACHIEVEMENT. Jurnal Tatsqif, 18 (2), 207-222. https://doi.org/10.20414/jtq.v17i2.2800

\section{CONCLUSION}

Islam Ummah in many parts of the world, including in Indonesia, often faces hard issues (of course the cases are not the same between one and other country). In the book of "Spirituality, Values and Mental Health: Jewels for the Journey" which summarizes inspiring tales from various circles and different religious beliefs who are mostly as the patients in the mental health institution who tell their life stories due to unjust treatment on what they believe in, so that, for the reader they can see fairly that every religious believer is the same, psychologically, in the case that they want to be respected, it very possible for whoever will experience things as they had, such as despair, violence, and even death.

Judging from the rampant violence based on religion that has emerged recently (for instance, internal-religious believer such as the tension between Sunni, Shi'a, Ahmadiyah, and Wahabi, between those who are veiled and not, also muddle between Banser and FPI, Islamic Radicalism Issues, and also inter-religious faith such as hate speech, blasphemy toward holy scripture, destructing worshipping place, even terrorism), so the textbook writer needs to insert the study from the psychological point of view in each learning material presented, or the student as the main figure as well as psychological object. Therefore, it is expected when this element is inserted, the purpose of learning itself can be well-delivered as planned.

Unfortunately, in Islamic Religious Education and Character in class 10 student's textbook by Kemendikbud RI 2007, it is not found learning material which inserts or contains psychological content (such as learning materials related to manifestation and spiritual/mental expression in the form of individual or group attitude that is possible to be inserted in a discourse, analogy, wisdom story, cases or moral guidance) inside of it will ease the student to be more understanding on Islamic teachings comprehensively correspond to the life problem issues challenges where they are living. 
Herlina, L. (2020). PSYCHOLOGICAL CONTENT IN ISLAMIC EDUCATION TEXTBOOK: A REQUIREMENT IN CHARACTER BUILDING GOALS ACHIEVEMENT. Jurnal Tatsqif, 18 (2), 207-222. https://doi.org/10.20414/jtq.v17i2.2800

\section{BIBLIOGRAPHY}

Abdullah bin Muhammad bin Abdurrahman bin Ishaq Alu Syaikh, Tafsir Ibnu Katsir Jilid 1-10, Jakarta: Pustaka Imam Asy-Syafi'i. 2011.

Al-Attas, Muhammad Naquib. The Concept of Education In Islam. A Framework Of An Filoshopy In Education. Kuala Lumpur. Muslim Youth Movement of Malaysia.1980.

Al-Qurán Terjemah. Departemen Agama RI. 2003

Araby (al), Abu Bakar Muhammad bin Abdillah Ibn, Aḥkām al-Qur"ān, jilid III, Mesir: Isa al-Bāb al-Halaby, 1957

Ahmadi, Abu \& Widodo Supriyono. 2003. Psikologi Belajar. Jakarta: Rineka Cipta.

Bahan Pelatihan Penguatan Metodologi Pembelajaran Berdasarkan Nilai-nilai Budaya untuk Membentuk Daya Saing dan Karakter Bangsa. Pusat Kurikulum Departemen Pendidikan Nasional. 2010.

Baba, Sidek. Pendidikan Rabbani: mengenal Allah melalui Ilmu Dunia. Selangor, Karya Bestari SDN. BHD. 2006.

Buku (siswa) Pendidikan Agama Islam dan Budi Pekerti kelas 10. Kemendikbud RI. 2017.

Baharun, H. Pendidikan Anak Dalam Keluarga; Telaah Epistemologis. Pedagogik. Jurnal Pendidikan, Vol. 3. No. 2. 2016.

Daradjat, Zakiyah, Ilmu Pendidikan Islam, Jakarta: Bumi Aksara, 2014.

Departemen Agama RI, Al-Qur'an dan Terjemahnya, Bandung: CV.Diponerogo, 2000.

Depdiknas. Peraturan Pemerintah RI No.19 Tahun 2005 tentang Standar Nasional Pendidikan. Jakarta: Depdiknas. 2008.

Ghazali, A. Ihya Ulum al-Din. I. (Terjem. . Yakub, Ed.) (Cet. 4). Singapura: Pustaka Nasional. 1992.

Hamalik, Oemar. Proses Belajar Mengajar. Jakarta: Bumi Aksara, 2011.

Hamka, Buya. Lembaga Hidup, Jakarta: Republika Penerbit, 2015.

Harsanti, Intaglia Dr. Dkk, Psikologi umum 1, Universitas Gunadarma. 2013. 
Herlina, L. (2020). PSYCHOLOGICAL CONTENT IN ISLAMIC EDUCATION TEXTBOOK: A REQUIREMENT IN CHARACTER BUILDING GOALS ACHIEVEMENT. Jurnal Tatsqif, 18 (2), 207-222. https://doi.org/10.20414/jtq.v17i2.2800

Imam Bukhari, Shaheh al-Bukhari, Semarang: Maktabah Toha Putra, 2004.

Kitab Undang-Undang Guru dan Dosen: UU RI No. 14 Th. 2005, Jakarta: Sinar Grafika. 2008.

Mahmud, H. Psikologi Pendidikan, Bandung: Pustaka Setia. 2010.

Muali, C. Rasionalitas Konsepsi Budaya Nusantara Dalam Menggagas Pendidikan Karakter Bangsa Multikultural. Jurnal Islam Nusantara, Vol. 1. No. 1. 2017.

Mujib, Abdul \& Mudzakir, Y. Nuansa-nuansa Psikologi Islam. Jakarta: Grafindo Persada. 2003.

Nizar, Prof. H. Samsul. Memperbincangkan Dinamika Intelektual dan Pemikiran Hamka tentang Pendidikan Islam. Penerbit: Prenada Media Grup Jakarta. Cetakan I Februari 2008.

Pratiknya Watik, Pendidikan dan Sumber Daya Manusia Menjelang Abad XXI, dalam PP Muhammadiyah, keputusan muktamar Muhammadiyah ke 43, Yogyakarta: Suara Muhammadiyah, 1995.

Spirituality, Values and Mental Health: Jewels for the Journey" Edited by Mary Ellen Coyte, Peter Gilbert dan Vicky Nicholls. Jessica Kingsley Publishers London and Philadelphia. 2007.

Young European Muslims, (2002). Islamophobia and The West. Young European Muslims 5 (2002):

Zuhairini dkk, Filsafat Pendidikan Islam, Jakarta: Buta Aksara, 2004. 